\title{
ISLAM DAN PERUBAHAN POLITIK
}

\section{Jamal Ghofir}

\begin{abstract}
When the internal Muslims have not been thorough in doing the equation of perception in the interpretation of Islamic political concepts. Already faced with foreign interests and interference in the agitation and propaganda of political concepts that refer to the Western political system. It is also a very difficult challenge for Muslims to implement and apply Islamic political concepts, even within the predominantly Muslim country.
\end{abstract}

Keywords: Islam, Change, Politics

\section{A. Pendahuluan}

Tak seorangpun menyangkal bila dalam Islam terkandung aspek-aspek politik. Berbagai sumber sahih menurut penelitian berasal dari masa-masa awal karir politik Nabi Muhammad SAW, ditemukan dokumen yang sangat tepat disebut sebagai “ Konstitusi Piagam Madinah”. Komentar yang dapat diberikan atas dokumen tersebuat adalah, isinya bukanlah merupakan hasil penemuan seorang teoritis politik, tetapi merupakan sesuatu yang sudah berakar dalam mentalitas dan adat-istiadat bangsa Arab pra-Islam. Sehingga setiap pertimbangan tentang sifat dasar negara Islam harus dimulai dengan melihat konsep-kansep politik yang telah menuntun aktifitas politik bangsa Arab praIslam (Watt, $1988: 7$ ).

Pondasi politik pemerintahan telah dibangun sebagai rujukan dalam menjalankan setiap kebijakan. Hal inilah yang seyogyanya diterapkan oleh penerus Rasulullah SWT. Walau dengan perjalanan waktu, pondasi awal politik dan sistem pemerintahan mulai mengalami kemunduran seiring dengan kepentingan golongan yang terjadi pada saat itu. Mulai dari kekhalifahan alKhulafaur al-Rasyidun, Khalifah Dinasti Umaiyah sampai pada Dinasti Abbasiyah. Dalam tulisan ini akan membahas tentang perubahan politik yang 
terjadi dalam Islam dari Republik menuju Monarki dengan keterbatasan pengetahuan sejarah penulis dan refrensi yang didapatkan.

\section{B. Rasulullah Sang Pemimpin Revolosioner}

Dalam rentan waktu kehidupan yang singkat dan beranjak dari lingkungan yang tidak menjanjikan, Nabi Muhammad SAW telah menginspirasikan terbentuknya sebuah bangsa yang tidak pernah bersatu sebelumnya, disebuah negeri yang hingga saat ini hanyalah sebuah ungkapan geografis, membangun sebuah agama yang luas wilayahnya mengalahkan Kristen dan Yahudi, serta diikuti sejumlah besar umat manusia; meletakan sebuah landasan bagi sebuah imperium yang dalam waktu singkat berhasil memperluas batas wilayahnya, dan membangun berbagai kota yang kelak menjadi pusat peradaban dunia. Meskipun tidak pernah dididik secara formal, Muhammad adalah pembawa kitab yang diyakini oleh seperdelapan penduduk bumi sebagi sumber ilmu pengetahuan, kebijakan, dan teologi (Hitti, 2002 : 152-154).

Muhammad juga sosok yang banyak makan asam garam pengalaman dan keahlian, profesi-profesi yang pernah ditekuninya seperti mengembala dan berdagang, disamping melakukan perjalanannya dan keluasan pergaulannya dengan para pemeluk ragam idiologi yang beraneka ragam, yang berduyun-duyun mengunjungi Makkah, tanah kelahirannya sekaligus yang menyuplainya dengan setok pengetahuan, kultur kebudayaan, dan maklumat yang luas dan panjang. Semuannya praktis menjadi bahan penyokong tersendiri bagi seorang penyeru teologi baru, penguasa negara, panglima perang, hakim penuntas segala sengketa, sekaligus mufti penasehat segala persoalan (Karim, 2005 : X-XI).

Rasulullah SAW mampu menciptakan pondasi-pondasi yang sangat elegan, dalam mengatur tatanan negara. Membentuk masyarakat yang dicitacitakan adalah bagian dari tugas kerasulan. Maka, ketika Rasul merasa tidak mungkin menciptakan tatanan ideal masyarakat pada fase Makkah, hijrah ke Madinah merupak jalan keluar terbaik. Terbukti dengan terbentuknya "Piagam Madinah" sebagai aturan yang harus ditaati oleh setiap masyarakat pada waktu itu. Kebijakkan politik Muhammad dituangkannya dalam suatu naskah politik 
dikenal dengan sebutan "Piagam Madinah”. Didalam Piagam Madinah terdapat kalimat yang mengandung makna dan mengarah pada kesatuan dan persatuan (Sukarja, 1995 : 99).

Semua sarjana mengetahui dan mengakui bahwa tindakan pertama Nabi Muhammad untuk mewujudkan masyarakat yang berkualitas itu adalah menetapkan suatu dokumen perjanjian Mitsaq al-Madinah (Piagam Madinah) yang dikalangan Barat juga dikenal sebagai “Konstitusi Madinah". Disebut sebagai konstitusi, karena Piagam Madinah adalah konsensus bersama yang berisi tata aturan hidup komunitas yang hidup di (negara) Madinah saat itu. Piagam Madinah menjadi ikatan peradaban (bond of civility) antara anggota masyarakat di Madinah telah mewujudkan masyarakat yang ideal, yaitu masyarakat demokratis (Nawy, : 100).

Setelah sepeninggalan Rasulullah SAW dikarenakan sakit kurang lebih tiga bulan setelah pelaksanaan haji wada' (Umari, 2003 : 313). Umat Islam mengalami kegundahan, tiada tempat untuk mengadu dan meminta nasehat kepada Rasulullah SAW. Kejutan akan meninggalnya Rasulullah Muhammad adalah salah satu krisis yang paling mencekam yang pernah dihadapi komunitas muslim. Dari sinilah bibit perpecahan mulai nampak dalam memilih penerus Rasulullah SAW . Sebagian besar sahabat Muhajirin mendukung Abu Bakar. Namun kaum Ansor menginginkan Sa'ad bin Ubadah. Keluarga Nabi percaya bahwa Nabi menginginkan Ali menggantikannya (Armstrong, 1996 : 378-379).

\section{Antara Konsep Dan Implementasi Politik Islam}

Islam adalah agama sekaligus Negara (al-islam huwa aldin wa al-dawlah). Keyakinan ini menancap kuat dalam memori kesadaran kolektif umat Islam, terutama para pemikir politik Islam dari dulu sampai sekarang. Akibatnya Islam di anggap sebagai satu-satunya agama yang memiliki ajaran yang paling utuh dan senantiasa sesuai dengan kebutuhan zaman. Selain itu, paradigma ini sering menggiring umat Islam untuk menampilkan agamanya dalam bentuk formal, yakni dengan menampakan wajah litelar bagunan politik Islam masa silam, tanpa usaha memodifikasi dan kontekstulaisai dengan kebutuhn realitas. Paradigma di atas lahir dari anggapan bahwa Nabi Muhammad selain sebagai Rasul juga 
seorang kepala Negara yang memiliki kewenangan mengatur kehidupan politik umat Islam. Nabi Muhammad SAW adalah peguasa tertinggi keagamaan sekaligus politik. Paradigma ini diperkokoh oleh romantisme khazanah Khulafaur Ar-Rasyidin dan dinasti-dinsati awal Islam yang banyak memberi sumbangan bagi peradaban Islam di masa lalu. Salah satu kontak romantisme khazanah Islam adalah penyamaan antara konsep syura' dalam Islam dengan demokrasi Barat. Hampir sebagian besar Negara muslim atau kependudukan mayoritas muslim, dahulu hingga saat ini. Penyamaan dan penyesuian ini berkembang hingga taraf di mana para pemikir muslim enggan mengunakan kata demokrasi dengan alasan kata syura dianggap lebih tepat dan lebih Islami untuk mengungkapkan pegertian yang dimaksud.

Paling tidak ada dua alasan, seperti dikemukakan Al-Jabiri yang kerap dijadikan argumen untuk menyamakan konsep syura' dan demokrasi. Pertama, bukan karena mereka mengetahui atau tidak mengetahui perbedaan antara keduanya, akan tetapi lebih karena kerangka aplikasi idielogis yang bertujuan agar pemuka agama yang fanatik menjadi tenang dengan seruan bahwa menerima demokrasi tidak berarti upaya memasukan bid'ah ke wilayah Islam. Kedua, aplikasi ideologis ini digunakan untuk mengangkat data-data dalam tradisi Islam guna menompang peradabanya ke tingkat modern. Implikasi yang diharapkan adalah masalah-masalah yang dihadapi umat Islam, kapan dan di manapun, dapat dipecah oleh tradisi agama dan pemikiranya sediri. Mekanisme ini di kenal sebagai mekanisme penguat identitas dan pembelaan diri.

Penyamaan kedua konsep politik di atas mendapatkan kritik dari Khalid Abdul Karim. Baginya, sinyalemen yang menyamakan antara syura' dan demokrasi tidak tepat. Sebab, perbedaan diantara keduanya sangatlah jelas. Bahkan, dalam kondisi bagaimana pun syura' tidak mungkin menjalankan fungsi demokrasi atau mengganti posisinya disebabkan karena sejarah keduanya berbeda seratus delapan puluh derajat. Dari sinilah dapat dilihat adanya perbedaan pemahaman pada konsep politik Islam dikalangan umat Islam sendiri apalagi pengimplementasian konsep politik Islam pada level negara. 


\section{a. Keragaman dalam Memahami Politik Islam}

Sudah menjadi hukum alam (sunnahtullah) bahwa umat manusia terdiri atas berbagai etnis, suku, ras, dan agama. Tidak seorangpun termasuk negara dengan segala kemampuannya, akan mampu merubahnya. Kemajemukan dan keberagaman dalam sebuah perbedaan baik pemahaman dan implementasi sebuah ajaran pada umat manusia sudah menjadi keniscayaan yang tidak bisa untuk dihilangkan. Begitu juga dalam memahami konsep terkait dengan politik keislaman yang telah dibangun pondasi-pondasinya oleh Rasulullah SAW dan para sahabatnya.

Agama, baik itu agama samawi, agama filosofis dan semua sistem lainnya, selalu mengasumsikan kemutlakan (doktrin) disamping metode yang tertuang dalam sistem ajaran, ritual dan tuntunan. Dalam kemutlakannya itu, suatu agama berfungsi sebagai pegangan dan tuntunan hidup yang memerlukan kadar kepastian yang tinggi, dan memberikan kepastian itulah fungsi pegangan atau tuntunan. Baik dalam hal politik (siyasah) maupun terkait dengan kehidupan berbangsa dan bernegara.

Karena itu, agama dalam maknanya yang paling esensial merupakan mengkonsepsikan satu pemahaman tentang pesan akan nilai-nilai universal sebagai rahmat seluruh umat dan bukan kekerasan maupun peperangan yang terkandung di dalamnya. Semangat inilah yang dikandung oleh setiap agama mengajarkan kedamaian, cinta kasih dan jauh dari kekerasan. Rentannya konflik yang berlatar belakang agama telah menjadikan problem kemanusiaan semakin jauh dari penyelesaian. Karena tindakan destruktif yang dilakukan manusia sering kali mengatasnamakan agama, maka agama lambat taun akan kehilangan ruh sucinya yang berakhir pada kaburnya nilai-nilai kemanusiaan yang dikandungnya.

Rasulullah SAW mampu menciptakan pondasi-pondasi yang sangat elegan, dalam mengatur tatanan negara. Membentuk masyarakat yang dicitacitakan adalah bagian dari tugas kerasulan. Maka, ketika Rasul merasa tidak 
mungkin menciptakan tatanan ideal masyarakat pada fase Makkah, hijrah ke Madinah merupak jalan keluar terbaik. Terbukti dengan terbentuknya "Piagam Madinah" sebagai aturan yang harus ditaati oleh setiap masyarakat pada waktu itu. Kebijakkan politik Muhammad dituangkannya dalam suatu naskah politik dikenal dengan sebutan "Piagam Madinah".

Teks al-Qur'an sebagi sumber dari segala sumber hukum dan Rasulullah SAW sebagai sumber hukum kedua setelah al-Qur'an menjadi pedoman pada saat itu. Setelah kepergian Rasulullah SAW pemahaman dan pemaknaan nilai-nilai yang terkandung dalam al-Qur'an mengalami kemajuan yang pesat dalam melakukan sebuah penafsiran hukum khususnya terkait dengan persoalan politik. Hal inilah yang menjadikan tidak adanya kesefahaman antar umat Islam sendiri dalam memahami konsep dalam Islam apalagi penerapannya dalam wilayah yang berskala besar seperti Negara.

\section{b. Dilema Politik Islam Antara Konsep dan Penerimaan}

Konsep politik Islam pada dasarnya telah terbangun sejak zaman Rasulullah SAW, sahabat dan para penerusnya. Hal ini membuktikan bahwasanya pondasi-pondasi dan peranan Islam dalam mengakomodir sebuah kepentingan politik telah terbangun sejak lama. Akan tetapi konsep yang telah tertata dengan baik belum diformalkan pada satu sistem yang pas. Sehingga peranan politik dan konsep Islam belum bisa diterima oleh banyak kalangan. Walaupun secara kuantitas semua berada pada idiologi yang sama pada ajaran Islam serta mayoritas berpenduduk Islam.

Banyak hal yang mempengaruhi belum bisa diterimanya konsep politik Islam pada suatu negara yang penduduknya mayoritas umat Islam. Hal ini menjadi bukti bahwasanya konsep politik dalam Islam belum memiliki peranan yang signifikan dalam kancah perpolitikan yang ada. Serta adanya perbedaan pemahaman dalam umat Islam sendiri serta adanya peranan kepentingan luar yang sengaja melakukan agitasi dan propaganda agar peranan politik Islam tidak bisa diterima oleh semua kalangan begitu juga dengan internal umat Islam itu sendiri. Belum lagi pertarungan antara konsep politik Islam dan konsep politik Barat 
senantiasa saling mengedepankan keunggulan masing-masing dalam menata dan mengaplikasikan peranannya dalam politik bernegara.

Konsep politik dalam internal umat Islam sendiri masih mengalami perdebatan yang panjang. Perbedaan yang terjadi dalam menafsirkan al-Qur'an dan Assunah menjadikan belum bertemunya satu kepentingan bersama dalam menerapkan konsep-konsep politik Islam itu sendiri. Belum lagi, kepentingankepentingan personal dari umat Islam sebagai manusia dalam melakukan eksistensinya dalam kehidupan dunia. Sehingga sesama umat Islam memiliki kepentingan yang berbeda dan melakukan penafsiran yang tidak seragam dalam mengimplementasikan konsep-konsep politik Islam dalam bingkai keislaman yang bertujuan untuk kepentingan Islam dan keumatan. Hal inilah yang menjadikan dilema dalam diri umat Islam untuk mengimplementasikan konsepkonsep politik Islam.

Ketika internal umat Islam belum tuntas dalam melakukan penyamaan persepsi dalam penafsiran konsep-konsep politik keislaman. Sudah dihadapkan dengan kepentingan dan campur tangan asing dalam melakukan agitasi dan propaganda konsep politik yang merujuk pada system politik Barat. Hal ini juga merupakan sebuah tantangan yang sangat berat bagi umat Islam dalam melakukan dan menerapkan konsep-konsep politk Islam, walaupun berada dalam negara yang mayoritasnya berpenduduk Islam.

Dilema politik yang terjadi akhirnya umat Islam menerima konsep politik Barat yang telah tersusun dengan baik dan sistimatis. Dibandingan dengan konsep politik Islam yang masih mengalami penafsiran dan perdebatan dikalangan umat Islam sendiri. Hal inilah yang menjadikan konsep politik Islam belum bisa diterima walaupun dalam negara yang mayoritas beragama Islam.

\section{Pertarungan Politik pada Masa Al-Khulafaur Al-Rasyidun}

Masalah perpolitikan intern negara Islam senantiasa berada dalam ketenangan selama masa Rasulullah SAW dan persatuan umat terwujud dengan baik. Jika terdai perbedaan pendapat di antara kaum muslimin, mereka segera menyerahkan masalah itu kepada Rasulullah SAW, kemudian Beliau memutuskan 
masalah mereka dengan hak dan adil dan mereka berkuwajiban untuk mentaati keputusan Rasulullah SAW tersebut ( Rais, 2001 : 10).

\section{Masa Khalifah Abu Bakar}

Setelah wafatnya Nabi Muhammad SAW status sebagai Rasulullah tidak dapat diganti oleh siapapun (khatami al-anbiya' wa al-mursalin), tetapi kedudukan beliau yang kedua sebagai pimpinan kaum muslimin mesti segera ada gantinya. Orang itulah yang dinamakan "Khalifah" artinya yang menggantikan Rasulullah SAW menjadi kepala kaum muslimin (pimpinan komunitas Islam) dalam memberikan petunjuk ke jalan yang benar dan melestarikan hukum-hukum Agama Islam. Dialah yang menegakkan keadilan yang selalu berdiri diatas kebenaran.

Abu Bakar menerima jabatan Khalifah pada saat umat Islam dalam keadaan krisis dan gawat. Yaitu timbulnya perpecahan, munculnya para nabi palsu dan terjadinya berbagai pemberontakan yang mengancam eksistensi negeri Islam yang masih baru. Memang pengangkatan Abu Bakar berdasarkan keputusan bersama (musyawarah di balai Tsaqifah Bani Sa'idah) akan tetapi yang menjadi sumber utama kekacauan ialah wafatnya nabi dianggap sebagai terputusnya ikatan dengan Islam, bahkan dijadikan persepsi bahwa Islam telah berakhir.

Abu Bakar bukan hanya dikatakan sebagai Khalifah, namun juga sebagai penyelamat Islam dari kehancuran karena beliau telah berhasil mengembalikan umat Islam yang telah bercerai berai setelah wafatnya Rasulullah SAW. Disamping itu beliau juga berhasil memperluas wilayah kekuasaan Islam. Jadi dapat disimpulkan bahwa letak peradaban pada masa Abu Bakar adalah dalam masalah agama (penyelamat dan penegak agama Islam dari kehancuran serta perluasan wilayah) melalui sistem pemerintahan (kekhalifahan) Islam.

Akan tetapi konsep kekhalifahan dikalangan Syi'ah masih ditentang. Menurut Syi'ah kekhalifahan adalah warisan terhadap Ali dan kerabatnya, bukan pemilihan sebagaimana terjadi pada Abu Bakar. Terlepas dari perbedaan interpretasi tersebut, dapat disimpulkan bahwa konsep kekhalifahan adalah produk budaya dibidang politik yang orisinil dari peradaban Islam. Sebab ketika itu tidak ada lembaga manapun yang memakai konsep kekhalifahan. 
Pengangkatan Abu Bakar sebagai Khalifah (pengganti Nabi) sebagaimana dijelaskan pada peristiwa Tsaqifah Bani Sa'idah, merupakan bukti bahwa Abu Bakar menjadi Khalifah bukan atas kehendaknya sendiri, tetapi hasil dari musyawarah mufakat umat Islam. Denga terpilihnya Abu Bakar menjadi Khalifah, maka mulailah beliau menjalankan kekhalifahannya, baik sebagai pemimpin umat maupun sebagai pemimpin pemerintahan. Adapun sistem politik Islam pada masa Abu Bakar bersifat "sentral", jadi kekuasaan legislatif, eksekutif dan yudikatif terpusat ditangan Khalifah, meskipun demikian dalam memutuskan suatu masalah, Abu Bakar selalu mengajak para sahabat untuk bermusyawarah.

\section{Masa Khalifah Umar bin Khatab}

Umar bin Khatab adalah keturunan Quraisy dari suku Bani Ady. Suku Bani Ady terkenal sebagai suku yang terpandang mulia dan berkedudukan tinggi pada masa Jahiliah. Umar bekerja sebagai saudagar. Beliau juga sebagai duta penghubung ketika terjadi suatu masalah antara kaumnya dengan suku Arab lain. Sebelum masuk Islam beliau adalah orang yang paling keras menentang Islam, tetapi setelah beliau masuk Islam dia pulalah yang paling depan dalam membela Islam tanpa rasa takut dan gentar.

Periode kekhalifahan Umar tidak diragukan lagi merupakan "abad emas" Islam dalam segala zaman. Khalifah Umar bin Khattab mengikuti langkahlangkah Rasulullah SAW dengan segenap kemampuannya, terutama pengembangan Islam. Ia bukan sekedar seorang pemimpin biasa, tetapi seorang pemimpin pemerintahan yang professional. Ia adalah pendiri sesungguhnya dari sistem politik Islam. Ia melaksanakan hukum-hukum Ilahiyah (syariat) sebagai code (kitab undang-undang) suatu masyarakat Islam yang baru dibentuk.

Maka tidak heran jika ada yang mengatakan bahwa beliaulah pendiri daulah Islamiyah (tanpa mengabaikan jasa-jasa Khalifah sebelumnya). Banyak metode yang digunakan Umar dalam melakukan perluasan wilayah, sehingga musuh mau menerima Islam karena perlakuan adil kaum Muslim. Di situlah letak kekuatan politik terjadi. Dari usahanya, pasukan kaum Muslim mendapatkan gaji dari hasil rampasan sesuai dengan hukum Islam. Untuk mengurusi masalah ini, telah dibentuk Diwanul Jund (Majid, 1978:86). Sedangkan untuk pegawai biasa, 
di samping menerima gaji tetap (rawatib), juga menerima tunjangan (al-itha'). Khusus untuk Amr bin Ash, Umar menggajinya sebesar 200 dinar mengingat jasanya yang besar dalam ekspansi. Untuk Umar bin Yasar, diberi 60 dinar disamping tunjangan (al-jizyaat) karena hanya sebagai kepala daerah (al-amil).

Dalam rangka desentralisasi kekuasaan, pemimpin pemerintahan pusat tetap dipegang oleh Khalifah Umar bin Khattab. Sedangkan di propinsi, ditunjuk Gubernur (oramg Islam) sebagai pembantu Khalifah untuk menjalankan roda pemerintahan. Di antaranya adalah :

1. Muawiyah bin Abu Sufyan, Gubernur Syiria, dengan ibukota Damaskus.

2. Nafi' bin Abu Harits, Gubernur Hijaz, dengan ibu kota Mekkah.

3. Abu Musa Al Asy'ary, Gubernur Iran, dengan ibu kota Basrah.

4. Mughirah bin Su'bah, Gubernur Irak, dengan ibu kota Kufah.

5. Amr bin Ash, Gubernur Mesir, dengan ibu kota Fustat.

6. Alqamah bin Majaz, Gubernur Palestina, dengan ibu kotai Jerussalem.

7. Umair bin Said, Gubernur jazirah Mesopotamia, dengan ibu kota Hims.

8. Khalid bin Walid, Gubernur di Syiria Utara dan Asia Kecil.

9. Khalifah sebagai penguasa pusat di Madinah .

\section{Masa Khalifah Ustman bin Affan}

Diantara Khulafaurrasyidin adalah Ustman Ibnu Affan (Khalifah ketiga) yang memerintah umat Islam paling lama dibandingkan ketiga Khalifah lainnya. Ia memerintah selama 12 tahun. Dalam pemerintahannya, sejarah mencatat telah banyak kemajuan dalam berbagai aspek yang dicapai untuk umat Islam. Akan tetapi juga tidak sedikit polemik yang terjadi di akhir pemerintahannya. Pada masa Khalifah Ustman, konsep kekhalifaan sudah mulai mundur, dalam arti interest politik di sekitar Khalifah mulai banyak diwarnai oleh dinamika kepentingan suku dan perbedaan interpretasi konsep kepemimpinan dalam Islam. Ketika itu sebenarnya Umar telah memilih jalan demokratis dalam menentukan penggantinya. Akan tetapi beliau berada dalam pada posisi dilematis, ia diminta oleh sebagian sahabat untuk menunjukkan penggantinya. Maka jalan keluar yang ditempuh Khalifah Umar adalah memilih formatur 6 orangyang terdiri dari: Ustman bin Affan, Ali Ibnu Abi Thalib, Thalhah, Zubair, Ibnu Awwam, Sa'ad 
Ibnu Abi Waqqas dan Abdurrahman Ibnu Auf (Syalaby, 1982:267). Kemudian formatur sepakat memilih Ustman sebagai Khalifah. Terpilihnya Ustman sebagai Khalifah ternyata melahirkan perpecahan dikalangan pemerintahan Islam. Pangkal masalahnya sebenarnya berasal dari persaingan kesukuan antara bani Umayyah dengan bani Hasyim atau Alawiyah yang memang bersaing sejak aman pra Islam. Oleh karena itu, ketika Ustman terpilih masyarakat menjadi dua golongan, yaitu golongan pengikut Bani Ummayyah, pendukung Ustman dan golongan Bani Hasyim pendukung Ali. Perpecahan itu semakin memuncak dipenghujung pemerintahan Ustman, yang menjadi simbol perpecahan kelompok elite yang menyebabkan disintegrasi masyarakat Islam pada masa berikutnya.

\section{Konflik dan Kemelut Politik Islam}

Pemerintahan Ustman berlangsung selama 12 tahun. Pada masa awal pemerintahannya, beliau berhasil memerintahan Islam dengan baik sehingga Islam mengalami kemajuan dan kemakmuran dengan pesat. Namun pada paruh terakhir masa kekhalifahannya muncul perasaan tak puas dan kecewa umat Islam terhadapnya. Khalifah Ustman adalah pemimpin yang sangat sederhana, berhati lembut dan sangat shaleh, sehingga kepemimpinan beliau dimanfaatkan oleh sanak saudaranya dari keluarga besar Bani Umayah untuk menjadi pemimpin di daerah-daerah.

Oleh karena itu, orang-orang menuduh Khalifah Ustman melakukan nepotisme, dengan mengatakan bahwa beliau menguntungkan sanak saudaranya Bani Umayyah, dengan jabatan tinggi dan kekayaannya. Mereka juga menuduh pejabat-pejabat Umayyah suka menindas dan menyalahkan harta baitul maal. Disamping itu Khalifah Utsman dituduh sebagai orang yang boros mengeluarkan belanja, dan kebanyakan diberikan kepada kaum kerabatnya sehingga hampir semuanya menjadi orang kaya.

Dalam kenyataannya, menurut Mufradi (1997:62) satu persatu kepemimpinan di daerah-daerah kekuasaan Islam diduduki oleh keluarga Khalifah Ustman. Adapun pejabat- pejabat yang diangkat Ustman antara lain:

1. Abdullah bin Sa'ad (saudara susuan Ustman) sebagai wali Mesir menggantikan Amru bin Ash. 
2.Abdullah bin Amir bin Khuraiz sebagai wali Basrah menggantikan Abu Musa Al-Asyari.

3. Walid bin Uqbah bin Abi Muis (saudara susuan Ustman) sebagai wali Kufah menggantikan Sa'ad bin Abi Waqos.

4. Marwan bin Hakam (keluarga Ustman ) sebagai sekretaris Khalifah Ustman.

Pengangkatan pejabat dikalangan keluarga oleh Khalifah Ustman telah menimbulkan protes keras di daerah dan menganggap Ustman telah melakukan nepotisme. Menurut Ali (1997:125), protes orang dengan tuduhan nepotisme tidaklah beralasan karena pribadi Ustman itu bersih. Pengangkatan kerabat oleh Ustman bukan tanpa pertimbangan. Hal ini ditunjukkan oleh jasa yang dibuat oleh Abdullah bin Sa'ad dalam melawan pasukan Romawi di Afrika Utara dan juga keberhasilannya dalam mendirikan angkatan laut. Ini menunjukkan Abdullah bin Sa'ad adalah orang yang cerdas dan cakap, sehingga pantas menggantikan Amr ibn 'Ash yang sudah lanjut usia. Hal lain ditunjukkan ketika diketahui Walid bin Uqbah melakukan pelanggaran berupa mabuk-mabukkan, ia dihukum cambuk dan diganti oleh Sarad bin Ash. Hal tersebut tidak akan dilakukan oleh Ustman, kalau beliau hanya menginginkan kerabatnya duduk di pemerintahan.

Situasi politik di akhir masa pemerintahan Ustman benar-benar semakin mencekam bahkan usaha-usaha yang bertujuan baik untuk kamaslahatan umat disalahfahami dan melahirkan perlawanan dari masyarakat. Misalnya kodifikasi al-Qur'an dengan tujuan supaya tidak terjadi kesimpangsiuran telah mengundang kecaman melebihi dari apa yang tidak diduga. Lawan-lawan politiknya menuduh Ustman bahwa ia sama sekali tidak punya otoritas untuk menetapkan edisi alQur'an yang ia bukukan. Mereka mendakwa Ustman secara tidak benar telah menggunakan kekuasaan keagamaan yang tidak dimilikinya (Mufradi, 1997:62).

\section{Masa Khalifah Ali bin Abi Thalib}

Dalam pemilihan Khalifah terdapat perbedaan pendapat antara pemilihan Abu bakar, Utsman dan Ali bin Abi Thalib. Ketika kedua pemilihan Khalifah terdahulu (Khalifah Abu Bakar dan Khalifah Ustman ibn Affan), meskipun mulamula terdapat sejumlah orang yang menentang, tetapi setelah calon terpilih dan diputuskan menjadi Khalifah, semua orang menerimanya dan ikut berbaiat serta 
menyatakan kesetiaannya. Namun lain halnya ketika pemilihannya Ali bin Abi Thalib, justru sebaliknya.

Setelah terbunuhnya Utsman bin Affan, masyarakat beramai-ramai datang dan membaiat Ali bin Abi Thalib sebagai Khalifah. Beliau diangkat melalui pemilihan dan pertemuan terbuka. Akan tetapi suasana pada saat itu sedang kacau, karena hanya ada beberapa tokoh senior masyarakat Islam yang tinggal di Madinah. Sehingga keabsahan pengangkatan Ali bin Abi Thalib ditolak oleh sebagian masyarakat termasuk Mu'awiyah bin Abi Sufyan. Meskipun hal itu terjadi, Ali masih menjadi Khalifah dalam pemerintahan Islam.

Pro dan kontra terhadap pengangkatan Ali bin Abi Thalib sebagai Khalifah dikarenakan beberapa hal yaitu bahwa orang yang tidak menyukai Ali diangkat menjadi Khalifah, bukanlah rakyat umum yang terbanyak. Akan tetapi golongan kecil (keluarga Umaiyyah) yaitu keluarga yang selama ini telah hidup bergelimang harta selama pemerintahan Khalifah Ustman. Mereka menentang Ali karena khawatir kekayaan dan kesenangan mereka akan hilang lenyap karena keadilan yang akan dijalankan oleh Ali. Adapun rakyat terbanyak, mereka menantikan kepemimpinan Ali dan menyambutnya dengan tangan terbuka. Beliau akan dijadikan tempat berlindung melepaskan diri dari penderitaan yang mereka alami (Syalaby, 1997:283).

\section{Kebijaksanaan Politik Ali bin Abi Thalib}

Menurut Thabani yang dikutip oleh Syalaby (1982:284-296) setelah Ali dibaiat menjadi Khalifah, ia mengeluarkan dua kebijaksanaan politik yang sangat radikal yaitu:

1. Memecat kepala daerah angkatan Ustman dan menggantikan dengan gubenur baru.

2. Mengambil kembali tanah yang dibagi-bagikan Ustman kepada familifamilinya dan kaum kerabatnya tanpa jalan yang sah.

Menanggapi kebijakan yang dilakukan oleh Ali tersebut, ada yang berpendapat bahwa kebijaksanaan Ali itu terlalu radikal dan kurang persuasive, sehingga menimbulkan perlawanan politik dari gubenur khususnya gubenur Syiria 
(Bani Ummayyah) yang tidak mau tunduk pada Khalifah Ali, terbukti ia menolak kehadiran gubenur yang baru diangkat Ali.

Penulis memandang bahwa tindakan politik Ali yang radikal itu kendati strategis tapi tidak taktis, sebab pada masa Khalifah Ustman konflik etnis antara Bani Ummayyah dan Bani Hasyim sudah ada, terbukti ketika Ustman terbunuh secara misterius, Bani Ummayyah mengeksploitasi tuduhan pada Ali, karena didasari Bani Umayyah yang memang ambisi menjadi Khalifah. Semestinya gerakan radikal Ali untuk mengusir elite Bani Umayyah dilakukan secara bertahap, sebab walau bagaimanapun elite baru yang telah lama berkuasa seperti Muawiyah sulit ditundukkan, sedangkan Ali yang mengandalkan idealisme dan dukungan masyarakat bawah beberapa kelompok tua terlalu intelektual tapi kurang pengalaman dalam menyelesaikan konflik dalam pemerintahan, sehingga dengan demikian yang muncul dalam pemerintahan bukan integrasi tetapi disintegrasi yang ditandai dengan lahirnya perang saudara yang pertama kali dalam Islam, yakni perang Jamal.

\section{E. Muawiyah Pencetus Pemerintahan Monarki}

Setelah melakukan propaganda dalam pemerintahan Ali bin Abi Thalib dan membunuh Hasan dengan memberikan racun, Muawiyah menjadi penguasa tunggal dan memindahkan ibu kota pemerintahan yang semula di Kufa dan sebelumnya lagi di Madinah berganti ke Damaskus. Khalifah Muawiyah yang pertama kali mengubah pemerintahan corak republik menjadi monarki (salthanat/kingship). Hal ini berdasarkan perkataan dari Muawiyah sendiri yaitu “ Saya Sultan Pertama" (I am the first king among the Arab kings). (Karim, 2009: 114).

Sistem pemerintahan yang turun-temurun diterapkan pada pemerintahan Muawiyah, terbukti dengan telah bergantinya kekhalifahan sebanyak 14 kali. Hal ini menjadikan ketidak simpatikan rakyat khususnya penduduk Makkah dan Madinah. Masa kekuasaan Yazid sangat singkat yaitu pada 680-683. Ia dibai'at oleh rakyat dengan setengah hati terutama penduduk Madinah dan penduduk Makkah. Walaupun pada masa kepemimpinannya berbentuk monarki namun masih ada Majelis Syuro yang menandakan pemerintahannya tetap demokratis. 
Para penguasa dinasti ini tetap memakai gelar "Khalifah" ada dewan syura, dan sebagai penguasa yang legitimet.

Dalam setiap perjalanan kehidupan selamanya tidak akan mampu bertahan pada satu titik kehidupan. Begitu juga dengan dinasti Umaiyah dalam menjalankan pemerintahannya yang monarki. Keruntuhan dinasti Umaiyah dikarenakan tidak maksimalnya komunikasi yang komunikatif setiap daerah dikarenakan terlalu luasnya daerah kekuasaan. Sehingga pergerakan perlawanan musuh sulit untuk dilakukan pendeteksian.

Dalam pemerintahan dinasti Umaiyah diantara empat belas khilfah yang memiliki kecakapan dalam memerintah dan mengendalikan keberadaan negara adalah Muawiyah, Abd al-Malik, al-Walid I, Sulaiman, Umar II dan Hisyam, selebihnya merupakan sosok khalifah dinasti Umaiyah yang lemah. Islam yang disebarkan oleh Rasulullah SAW penuh dengan perdamaian berubah menjadi alat legitimasi symbol politik pada masa dinasti Umaiyah. Hal ini menjadikan selalu adanya konflik antar golongan.

\section{F. Pemerintahan Monarki ala Dinasti Abbasiah}

Nama Dinasti Abbasiyah merupakan nama salah seorang paman Nabi Muhammad SAW yang bernama al Abbas ibn Abd al-Muttalib ibn Hasyim. Mereka menganggap bahwasanya orang Abbasiyah memiliki hak dalam kekhalifahan dalam Islam dibandingkan dengan Bani Umaiyah. Sebab mereka menganggap bahwasanya Bani Hasyim yang secara nasab keturunan lebih dekat dengan Rasulullah SAW. Sedangkan keberadaan Bani Umaiyah dalam khalifahan Islam lebih mengedepankan pemaksaan dalam melakukan perebutan kekuasaan. Hal ini terbukti ketika terjadi perang Sifin. Oleh karena itu, mereka melakukan gerakan-gerakan dasyat dan propaganda untuk melakukan pemberontakan pada Dinasti Umaiyah.

Gerakan bawah tanah yang dilakukan oleh Bani Abbas sebagai rival politik senantiasan menyusun kekuatan dan melakukan propaganda. Akan tetapi dalam melakukan propaganda tersebut tidak mengunakan identitas sebagai keluarga Abbas. Namun yang digunakan dalam agitasi pengambilan simpatik rakyat menggunakan Bani hasyim. Dengan demikian mereka dapat leluasa 
merangkul baik kelompok Ali maupun Abbas. Dan kedua kelompok inilah yang membidani berdirinya kekhalifahan Abbasiah.

Dalam pergulatan kehidupan tidak selamanya yang duduk di atas mampu mempertahankan kursi kekuasaanya. Begitu juga dengan Dinasti Abbasiah mengalami kehancuran dikarenakan dua faktor yaitu :

1. Internal, penguasaan wilayah yang sangat luas tidak mudah dikendalikan oleh khalifah yang lemah, eksploitasi dan pajak berlebihan menjadi kebijakan yang dibebankan pada rakyat, membangun kelompok tentara elit dari Turki secara terpisah dengan tentara Abbasiayah, tidak adanya aturan atau system yang baku dalam pergantian khalifah., perpecahan dan pertentangan antara Arabnon-Arab dan pertentangan antar umat Islam sendiri,Kaum zimmi yang tidak bahagia kembali berada pada naungan Islam, munculnya dinasti-dinasti kecil, factor prekonomian.

2. Eksternal, adapun factor dari luar adalah penyerangan bangsa Monggol.

\section{G. Corak Pemerintahan dari Republik ke Monarki}

Sistem pemerintahan sepanjang al-Khulafa al-Rasyidun telah menegasikan bahwasanya kepemimpinan yang berdaulat adalah adanya legitimasi yang kuat dari rakyat. Sebab pemerintahan pada masa al-Khulafa al-Rasyidun sebagai sebuah manifestasi akan keberadaan pemerintah sebagai pelayan rakyat bukan sebagai penguasa. Corak pemerintahan pada Dinasti Umaiyah adalah turuntemurun dari satu keturunan ke keturunan selanjutnya. Hal inilah yang menjadikan jurang antara Arab dan Mawali. Keterbukan yang dibangun dan memberikan ruang untuk berdiskusi pada masa al-khulafa al-Rasyidun dalam pengambilan kebijakan pemerintah merupakan satu lompatan corak kepeminpinan yang sangat demokratis.

Pada masa al-Khulafa al-Rasyidun sistem dekokrasi berjalan dengan baik sedangkan pada masa Dinasti Umaiyah suara rakyat tidak dihiraukan. Al-Qur'an, Hadis, dan Ijma' merupakan landasan dalam menjalankan suatu pemerintahan sedangkan dalam pemerintahan Dinasti Umaiyah perjalanan pemerintahan didasarkan atas kekuasaan dan segala kebijakan khalifah harus dipatuhi oleh rakyat. Kita ketahui bahwasanya kesederhanaan dalam mejalankan kehidupan 
sehari-hari dalam pemerintahan al-Khulafa al-Rasyidun diterapkan dengan baik. Sedangkan dalam pemerintahan Dinasti Umaiyah kehidupan merekan sangat mewah seperti raja-raja Persia dan Bizantium (Karim, 2009: 141-142).

Perjalanan pemerintahan mulai dari al-Khulafa al-Rasyidun (Republik) legitimasi kekuasaan ditangan rakyat, dan pada masa Dinasti Umaiyah (Monarki) legitimasi kekuasaan berada pada kekuatan penguasa (keterlibatan rakyat sangat sedikit). Sedangkan pada masa Dinasti Abbasiah kedaulatan ditangan Allah (devine origin). Sebagaimana ditegaskan oleh Khalifah Mansur, Ana khalifahtullahi fi ('ala al-Ard) Ardihi : saya adalah Khalifah Allah di muka bumiNya,... Ana Sultanullahi fi ('ala al-Ard) Ardihi : saya adalah kekuasaan Allah di muka bumiNya... dan Ana Zillullahi fi ('ala al-Ard) Ardihi : saya adalah bayangan Allah di muka bumiNya dan menjadi penuntun bagi kaum muslim. Oleh karena itu dalam kepemimpinan Dinasti Abbasiah sejak Mansur para khalifah tidak membutuhkan pengakuan rakyat tapi rakyatlah yang membutuhkan khalifah (Karim, 2009: 146-147).

\section{H. Penutup}

Perjalanan sejarah yang dimulai dari peranan Rasulullah SAW dalam membentuk dan membangun pondasi-pondasi peradaban Islam. Telah menunjukan dan sebagai rujukan dalam menjalankan roda pemerintahan bagi penerusnya. Etika politik yang begitu indahnya telah di terapkan dalam pemerintahan Rasulullah SAW.

Namun, setelah meninggalnya Rasulullah SAW etika politik yang telah di bentuk begitu bagusnya oleh Rasulullah SAW tidak bisa lagi diperlihatkan oleh para penerusnya. Penggunaan segala cara untuk mencapai kekuasaan senantiasa dipergunakan. Baik melalui propaganda-propaganda dalam penyebaran fitnah, pembangkangan, pemberontakan bahkan sampai pembunuhan guna melegitimasi sebuah kekuasaan.

Perjalanan sistem pemerintahan mulai dari berbentuk republik pada masa al-Khulafa al-Rasyidun yang menjadikan rakyat merupakan kedaulatan tertinggi dan pemimpin merupakan sebagai sarana atau pelayan dalam melayani rakyat. 
Masuk pada perubahan system pemerintahan pada masa Dinasti Umaiyah yang menjalankan sistem pemerintahan Monarki, kedaulatan ditangan khalifah atau penguasa sedangkan keberadaan rakyat tidaklah signifikan. Akan tetapi perubahan drastis pada Dinasti Abbasia, kedaulatan tertinggi ditangan Allah. Keberadaan rakyat tidak berpengaruh pada pemerintahannya sebab yang membutuhkan penguasa adalah rakyat, bukan penguasa yang membutuhkan rakyat. Perubahan sistem politik yang terjadi merupakan perjalanan sejarah dalam kepemimpinan Islam yang harus menjadi refrensi dalam kehidupan saat ini. Oleh karena itu, banyak hikmah yang dapat diambil dalam sejarah perjalanan politik dalam Islam dalam kehidupan berbangsa dan bernegara saat ini.

\section{Daftar Pustaka}

Abdul Karim, Khalil. 2005. Negara Madinah. Yogyakarta : LKiS.

Al-Umari, Akram Diya'. 2003. Tolak - Ukur Peradaban Islam. Yogyakarta : Ircisod.

Armstrong, Karen Muhammad. 1996. Sang Nabi Sebuah Biografi Kritis. Surabaya : Risalah Gusti.

Hitti, Philip K. 2002. History of The Arabs. Jakarta : PT Serambi Ilmu Semesta.

Karim, M Abdul . 2009 . Sejarah Pemikiran dan Peradaban Islam. Yogyakarta : Pustaka Book Publisher.

Montgomery Watt, W. 1988. Politik Islam dalam Lintasan Sejarah. Jakarta : CV. Guna Aksara.

Nawy, Ayang Utriza. Demokrasi dalam Konteks Piagam Madinah, Jurnal Tashwirul Afkar. Jakarta: Lakpesdam NU.

Rais, M. Dhiauddin. 2001. Teori Politik Islam. Jakarta : Gema Insani Press.

Sukarja, Ahmad. 1995. Piagam Madinah dan Undang-Undang Dasar 1945. Jakarta : UI- Press. 